\title{
8
}

\section{(Re)formulating the Social Question in Post-apartheid South Africa: Zola Skweyiya, Dignity, Development and the Welfare State}

\author{
Jeremy Seekings
}

\section{Introduction}

In 1994, for the first time, "African", "coloured" and "Indian" South Africans voted alongside their "white" counterparts in the country's first non-racial election. (For an explanation of terms used in South Africa, see glossary in Chap. 6). The African National Congress (ANC), led by Nelson Mandela, secured a substantial majority, and Mandela became President. For almost three years he presided over a Government of National Unity, in which the ANC participated alongside the party of apartheid, the National Party, ${ }^{1}$ although real power lay with the ANC. From early 1997, the ANC governed alone. The ANC's core support base comprised the African majority of the population that had been most oppressed under apartheid and remained largely disadvantaged as of 1994.

${ }^{1}$ As well as the Zulu nationalist Inkatha Freedom Party.

J. Seekings $(\bowtie)$

University of Cape Town, Cape Town, South Africa 
Unsurprisingly, the social question was redefined. For the first time in South African history, all South Africans were full citizens, with the full social and economic rights of citizenship as much as political rights. Given the enduring racialised pattern of disadvantage, the social question was inevitably going to be redefined to focus unambiguously on the experiences of black, and especially African, South Africans. Prior to 1994, the South African state had often been concerned with poverty or wages or employment among white South Africans (and, in the 1980s, coloured and Indian South Africans), but only occasionally with how these issues were experienced by the African majority. In the 1980s, the apartheid state had redefined the social question in response to the threat to it posed by protesting black workers, students and other township residents and sought to win them over or at least to secure their acquiescence through modest policy reforms. But this political opportunism was halfbaked as well as belated. Democratisation in 1994 marked a far more radical rupture with the past.

Democratisation opened up multiple possibilities of change. Whilst African people had all experienced discrimination and oppression under apartheid, different classes within the African population put forward their distinct claims to redress and thus sought to reframe the social question in their own, often sectional interests. African workers, organised into powerful trade unions, demanded higher wages and improved conditions of employment. The African middle classes, from whom much of the political elite came, demanded improved opportunities in professional and managerial occupations. The rapidly forming African elite, including much of the political leadership, demanded opportunities to seize a share of the country's wealth through "Black Economic Empowerment" (both legal and corrupt). The urban and rural poor wanted jobs and improved public services. The ANC was pulled and pushed by all of these demands.

The result was contestation over precisely how the social question was to be reframed. For African industrial workers - organised into powerful trade unions, with close ties to the ANC and a strong intellectual wingthe social question entailed primarily a racialised version of the struggle over inequalities generated through capitalist relations. The unions denounced the apartheid (or racial) "wage gap", between highly paid, 
skilled, managerial and professional occupations (disproportionately filled by white South Africans) and unskilled and semi-skilled occupations (mostly filled by African South Africans). They demanded and quickly secured basic social democratic reforms: strengthened processes for collective bargaining over wages and conditions of employment (and for setting minimum wages in unorganised sectors); corporatist policymaking institutions; and worker-oriented skills development. These reforms entailed further expansion of South Africa's system of "semisocial" insurance for workers in formal employment. Workers in formal employment in most economic sectors were required to contribute to pension funds and, to a lesser extent, private health insurance. Most of these funds were, in practice, run by the trade unions. The government's unemployment insurance fund was extended, at least nominally. Unionised workers-more and more of whom were more middle- than working-class-became, in important respects, economic "insiders", concentrated in high-productivity sectors or the protected public sector.

For the African middle classes and elite, the social question revolved around the substitution of race-based affirmative action in place of apartheid-era racial discrimination, to open up rapidly opportunities for upward economic and social mobility. The fast-growing African middle classes and elites (at least outside of public sector employment) looked primarily to the private sector for their retirement pensions and health insurance (as well as for healthcare and the education of their children). High earners were not allowed to claim from the Unemployment Insurance Fund.

For the largest part of the population, however, the social question revolved around poverty and effective exclusion from the economy. Almost no one in the poorest half of the population enjoyed formal employment or trade union membership or access to the educational credentials required for highly paid occupations or the connections required for wealth accumulation. Without land, formal employment, educational credentials or connections, the poor were "outsiders" from the largely capitalist economy (Seekings and Nattrass 2005, 2015). Trade unions generally neglected workers outside of formal employment and the unemployed (Bramble and Barchiesi 2003; Buhlungu 2010). Indeed, the success of organised labour in addressing the "worker's question" 
arguably framed the poverty question by pushing the economy down a skill- and capital-intensive economic growth path. The poorest half of the population enjoyed some power as voters and through the use (or threat) of direct action. These forms of power were limited, however, by the design of the electoral and political systems, especially in comparison with the power of other, non-poor classes (Seekings and Nattrass 2015). The poor thus remained heavily dependent on how poverty and the poor themselves were perceived by the country's more powerful political players, including especially the ANC leadership.

Given the success of the black elite, middle class and organised working class in accessing improved opportunities and standards of living, the fundamental post-apartheid social question revolved around poverty and crucially around elite perceptions of poverty and the poor. Under ANC governments, for the first time, poverty moved to the forefront of the rhetoric of the governing party and new state. The questions of workers' rights and racial redress were at least as important in terms of commanding the attention of the government, but the unresolved poverty question framed successive government documents and ANC election manifestos. $^{2}$ In the late 1990s ANC ministers and ANC-appointed officials reframed poverty as a largely developmental problem, representing the poor as the victims of apartheid in the sense that apartheid had denied them opportunities - just as it had denied fair opportunities to black workers or the aspirant middle classes and elite. In the 2000s, the social question was reframed, emphasising more the legitimacy of a claim (or right) to dignity on the part of the poor. This was reflected in the acknowledgement of the importance of social assistance programmes as a necessary and effective mechanism for mitigating poverty. The reframing of the social question was shaped by the rights talk associated with the postapartheid constitution (and subsequent jurisprudence) and promoted strongly by civil society, as well as by the imperatives of electoral competition. Within government, the person who was most responsible for the embrace-and subsequent expansion-of social assistance was Zola Skweyiya, the minister responsible for Welfare (or "Social Development",

\footnotetext{
${ }^{2}$ Several other "questions", including the "land question" and questions of enduring discrimination against women and other groups, were far less of a priority.
} 
as it was renamed) from 1999 to 2009 . This chapter examines, first, the ANC's developmental ambitions between 1994 and 1999, then turns to Skweyiya's successful efforts to legitimate social assistance during the 2000 s and, finally but briefly, considers the period of partial reaction after 2009.

This chapter does not consider in detail the policies adopted in response to the reframing of the social question because these have been documented extensively elsewhere. In summary, the state's policies to create jobs were misguided and unsuccessful. Rather than emphasise the creation of jobs in labour-intensive sectors for unskilled workers, government policy focused on raising productivity and wages, resulting in more capital- and skill-intensive production in the formal economy. The inadequate numbers of new "jobs" entailed mostly low-earning selfemployment in the informal economy. Government policy was especially unfortunate in view of the failure to improve the quality of public education and hence continued shortages of skilled labour. Successive ANC governments also failed to expand agricultural livelihoods. The primary cause of a slow reduction in poverty rates in the 2000s was therefore not employment but rather the social assistance system, inherited from apartheid but expanded through (primarily) a new Child Support Grant. The basic shape of the social welfare system remained unchanged, however, with a limited social insurance system and large holes in the social safety net. The combination of rising unemployment and an inadequate social assistance safety net was that poverty persisted (Seekings and Nattrass 2015; Nattrass and Seekings 2019).

\section{"Poverty Knowledge" and the Developmental Imperative (1994-1999)}

The ANC formed a government in 1994 alert to the scale of the challenge of poverty. The previous year, the ANC had backed an initiative by the World Bank and the University of Cape Town (UCT) to map poverty through South Africa's first countrywide income and expenditure survey (Wilson 1996). The apartheid state had never collected good data on 
countrywide poverty. The 1993 survey was led by UCT Professor Francis Wilson, who in the 1980s had led a research programme on poverty that brought together local and thematic studies (see Wilson and Ramphele 1989). The 1993 survey provided the "scientific" data-or "poverty knowledge" — that had been lacking hitherto (see Davie 2015). Using a poverty line set at about R840 (i.e. about US\$250, at the time) per month for an urban family comprising two adults and three children, and at a slightly lower level in rural areas, almost one half of the population of South Africa lived in poverty. In some parts of the country-notably the Eastern Cape and Northern Transvaal - about two-thirds of the population lived in poverty (Whiteford et al. 1995). The poverty line widely used within South Africa was about 60 per cent more generous than the standard international poverty measure of (at the time) US $\$ 1$ per person day (adjusted for local purchasing power). Even using the austere $\$ 1 /$ day measure, however, as many as one in four South Africans lived in poverty, which was a much higher proportion than in other countries with similar levels of development or GDP per capita.

At the same time, few ANC leaders had much recent experience in the poorest, rural parts of the country. Many had spent as long as three decades in exile or jail. Most of the ANC's "internal" leadership was drawn from urban areas. In the social welfare policy field, ANC activists were drawn primarily from the urban Western Cape, where they were especially familiar with the failings of apartheid-era social work and in some cases had been involved in community-based struggles over housing, rents and service delivery. Few ANC policymakers had close and recent experience of rural poverty.

The ANC first spelt out its understanding of and response to poverty in its 1994 Reconstruction and Development Programme (RDP, which served as an extended election manifesto). Poverty was described as "the single greatest burden on South Africa's people". The ANC promised "a better life for all". "Attacking poverty and deprivation" would be "the first priority of the democratic government". The poor would be empowered "to sustain themselves through productive activity". The government's primary responsibility would be to "create opportunities for all South Africans". This would be supplemented with a safety net based on social security (ANC 1994). In his inaugural State of the Nation address, 
Mandela committed his government to ensuring that South Africans enjoyed freedom from want, hunger and deprivation, as well as political freedoms. These, he said, were "fundamental to the guarantee of human dignity". They would be achieved through reconstruction and development. In his address, Mandela sketched a minimal safety net: primary school feeding schemes and workfare. His government would "confront the scourge of unemployment", he added, "not by way of handouts but by the creation of employment opportunities". ${ }^{3}$

The ANC inherited a significant safety net, despite the fact that the National Party-in government through the entire apartheid periodhad been deeply ambivalent about the welfare state (Seekings 2020). In 1994 , just over two million elderly or disabled people received meanstested, non-contributory old-age pensions or disability grants. About half a million other social grants were paid out. The total cost of these social assistance programmes came to more than 2 per cent of GDP. Racial discrimination in benefits had been abolished prior to the 1994 elections, although racial discrimination persisted in terms of access to some of the programmes. Social and semi-social insurance programmes provided little in the way of a safety net for the poor. Despite the importance of social assistance in mitigating poverty, the new ANC government was not enthusiastic. In his inaugural presidential address, Mandela himself denounced "handouts". 4

After winning the election, the ANC formed a coalition government with the National Party. The Ministry of Welfare was one of the few ministries given to the National Party, which reflected its perceived insignificance. An ANC Member of Parliament (Geraldine Fraser-Moleketi) was appointed as deputy-minister, and an ANC-aligned academic and activist (Dr Leila Patel) was appointed as a special advisor to guide the process of drafting a new "white paper" (i.e. government policy proposals) on social welfare. In January 1996 Patel was appointed as director-general (i.e. senior bureaucrat) in the Department of Social Welfare. In mid-1996, the ANC's Fraser-Moleketi took over as minister.

\footnotetext{
${ }^{3}$ Mandela, State of the Nation Address, 24 May 1994; available on https://www.gov.za/ state-nation-address.

${ }^{4}$ Mandela, State of the Nation Address, 24 May 1994; available on https://www.gov.za/ state-nation-address.
} 
Through the 1990s the ANC-led government framed the challenge of poverty using three primary discourses: a conservative discourse focused on but not limited to costs; a technocratic discourse emphasising the authority of statistical measurement; and-especially-a developmental discourse (or, more accurately, ideology). Each of these three played its part in reframing the social question. The discourse of paternalistic conservatism later articulated by Skweyiya (see later) was very muted during this period.

The Department of Welfare emphasised the unaffordability of the social assistance system inherited from apartheid. In the face of "spiralling" costs, the government concluded that it could "no longer afford the social security function". The Department would "re-evaluate" social security to render it more cost-effective. Expenditures would be reduced by "eliminating" fraud, which were said to cost as much as 10 per cent of the social assistance budget. Applying the means test more strictly would also save "millions of rands" (South Africa 1995: 7; 1996: 20). A pressing dilemma was what to do about the State Maintenance Grant (for poor single mothers), which in practice excluded African people. Faced with a prospective bill amounting to about 2 per cent of GDP - that is, doubling expenditure on social assistance-if the exiting programme was extended to the whole population, the government's first instinct (in 1995) was to propose doing away with the programme (Lund 2008: 18-19).

These sentiments might have been promoted by the continued role of the National Party within the Department of Welfare during 1994-1997, but they also fitted with powerful sentiments within the ANC. ANC leaders and ANC-aligned officials seem to have associated social grants with apartheid-era social work, which focused on the supposed failings of individuals and the ensuing need for individual casework. The ANC wanted a more modern approach.

The ANC's modernism was both reflected in and pushed forward by its investment in statistical data. The South African state had for many decades demonstrated a "mania for measurement" (Posel 2000), albeit selectively (e.g. never measuring poverty among the entire population) (see also Davie 2015). The post-1994 state took this passion for measurement to new heights. The parastatal Statistics South Africa was 
transformed: besides collecting standard economic and demographic data, it initiated annual household surveys and a five-yearly income and expenditure survey. The government also commissioned a major study of poverty and inequality. The ensuing data demonstrated, again and again, the extent of poverty. Poverty on this scale could not be due to the failings of any individuals but must rather have structural roots. For the ANC it was obvious that apartheid was the cause of South Africa's pervasive poverty because apartheid had denied black South Africans the opportunities to prosper. Vice-President Thabo Mbeki articulated this in his description in 1998 of South Africa as comprising "two nations": one, white and prosperous, the other, black and poor (see Nattrass and Seekings 2000).

What was needed was the abolition of racially discriminatory constraints on black South Africans and a massive programme of "reconstruction and development" (the RDP)—echoing the language used to frame state-driven programmes in Europe, following the Second World War. The ANC's priority was to promote development, not to expand "welfare" through either social grants or social work. The Department of Welfare said that it accepted the need for social grants but, "to ensure that those receiving welfare do not become permanently dependent on state aid, social grants for certain target groups will be closely linked to job creation and other anti-poverty programmes. Successful development programmes will empower people to earn a living, move off the social security system and achieve economic independence" (South Africa 1996: 19-20). As Mandela himself explained in speeches, the poor would achieve dignity through self-help, that is, through taking advantage of the opportunities that would open up now that apartheid had been abolished. In his 1996 State of the Nation Address, Mandela appealed to the poor not to "sit back, expecting charity" (whilst also urging the rich to stop viewing the poor as "hordes of irritants"). ${ }^{5}$ The ANC bought into the developmentalist ideology that had been hegemonic in Africa in earlier decades (Mkandawire 1999), along with the anxieties about "dependency" that often accompanied it (see, e.g. Seekings 2017a).

\footnotetext{
${ }^{5}$ Mandela, State of the Nation Address, 9 February1996; available on https://www.gov.za/ state-nation-address.
} 
The new developmentalism was central to the White Paper for Social Welfare, drafted through a consultative process in 1995-1996 under Patel's leadership and then published in August 1997. The White Paper committed the government to the goal of "developmental social welfare" and "re-orienting [its] services towards developmental approaches". This meant helping people to meet their own needs, through "the development of human capacity and self-reliance", rather than relying on the state: "South Africans will be afforded the opportunity to play an active role in promoting their own well-being and in contributing to the growth and development of our nation". The developmental emphasis was perhaps aimed primarily at professional social work (which was "largely rehabilitative" rather than "preventative and developmental"), and the White Paper did commit itself to the principle of "appropriate social assistance for those unable to support themselves and their dependents". But the emphasis was clearly placed on enhancing the capacity of "vulnerable individuals and families ... to earn a living through employment creation, skills development, access to credit and, where possible, through facilitating the transition from informal to formal employment". This encouraged a critique of the "welfare state" for promoting "dependency" through unearned "hand-outs". The White Paper itself proposed the establishment of a government unit "to identify groups of beneficiaries who could be absorbed into public works and other employment programmes" and seemed to envisage that the old-age pension programme would be scaled back as contributory pension programmes expanded (South Africa 1997; see further Patel 2005; Gray 2006). As the Minister of Welfare, Fraser-Moleketi, told parliament, "welfare has become associated with charity and hand-outs, with food parcels and pensions, something in which it was alleged bleeding hearts got involved". She called for a shift in thinking about "welfare", "from paternalism to self-reliance" and investment in development. ${ }^{6}$

This new approach was shaped by ideas from outside of South Africa. One important influence was the work of the South African-born but later US-based scholar James Midgley, whose book Social Development:

\footnotetext{
${ }^{6}$ Debate on Appropriation Bill, Vote no.37-Welfare, Wed 27 May 1998, Hansard, col 3193-5, 3201.
} 
The developmental perspective on social welfare was published in 1995. Midgley's book advocated "social development" as a new approach to social welfare distinguished by "its attempt to harmonize social policies with measures designed to promote economic development. ... It stresses the need for a wider commitment to economic develop-ment and emphasises the importance of social interventions that are compatible with economic development objectives" (Midgley 1995: 1-2). Midgley's description of "distorted development" across much of the "Third World", informed no doubt by his adolescence in South Africa, resonated with South African policymakers after 1994. Patel $(2014,2015)$ acknowledges the deep influence of Midgley's work, as well as of the UN World Summit for Social Development held in Copenhagen in 1995 (see also Gray 2006). Whilst Midgley and Patel were not hostile to social grants, nor (at that time) were they enthusiasts.

This thinking shaped the reform of the State Maintenance Grant, which was to have far-reaching and not entirely intended consequences. The grant provided generous support to poor, single mothers, but almost entirely excluded South Africa's black African population. When it was pointed out that abolishing the programme would cause massive hardship, the government appointed a committee to be chaired by another social work academic and activist, Francie Lund. The Department of Welfare described the Lund Committee's brief as to "look at ways of linking social grants with developmental programmes, so that single parent families can move towards becoming self-supporting". It would also look at ways of making absent parents contribute to the costs of raising their children (South Africa 1996: 22). In its report, completed in late 1996, the Lund Committee recommended that the State Maintenance Grant be replaced with a new Child Support Grant that would be rolled out to the entire population from 1999. Accepting tight fiscal constraints, the Committee had to recommend that benefits be parsimonious and older children be excluded (Lund 2008).

The government's thinking was clearly set out by Fraser-Moleketi in speeches to parliament. In early 1997 she declared that:

With regard to poverty, we believe that development goes beyond redistribution and safety-net measures and implies a pattern of growth facilitated 
by carefully designed Government interventions to reduce poverty and inequality. ... We intended to ensure that there is a restructuring of the social security system ... to foster the ability of the poor in our country to produce their way out of poverty through programmes which will generate and enhance livelihood as a fact and means of achieving household food security. ${ }^{7}$

Later in 1997, she told parliament that the new emphasis on developmental welfare would "empower individuals and communities so that they can break out of the poverty trap". She reaffirmed the government's "commitment to poverty reduction through cash transfers which supplement the household incomes of poor families", that is, the safety net. But, "welfare expenditure" had reached "its ceiling" so that in future budgetary allocations would increase slowly:

The challenge facing us is to use the available resources optimally and bring about savings in the total welfare function through aligning expenditure with priorities, promoting greater efficiency and accountability in delivery and ensuring that programmes are well targeted at those in the greatest need and that the design of programmes is appropriate and cost-effective. ${ }^{8}$

The modesty of the benefits under the proposed new Child Support Grant was justified on the basis that resources should be directed to other, more developmental programmes (especially during a period of fiscal crisis):

In an ideal world, I too would wish to be able to spend more on social security in the immediate term. However, in a developing country such as ours, we have to balance competing demands and decide how to use scare resources in the most effective way. Ultimately, the most effective antidote to poverty is for all our people to have a meaningful stake in the economy. While administering cash transfers, the Ministry of Welfare, in collaboration with other ministries, has embarked on a number of projects aimed at

\footnotetext{
${ }^{7}$ Fraser-Moleketsi, Hansard, House of Assembly, response to State of the Nation Address, 11 Feb 1997, col 41.

${ }^{8}$ Fraser-Moleketsi, Hansard, House of Assembly, Budget vote, 8 May 1997, col 2309-14.
} 
giving a hand up to the many who remain excluded from the mainstream economy. ${ }^{9}$

The Department of Welfare's flagship programme was a training programme for unemployed women with young children that would reduce their "dependence" on social grants. In early 1999, as the new Child Support Grants were being rolled out, Fraser-Moleketi told Parliament of women who had been "dependent on state maintenance grants" but who were now earning much more through projects such as brick-making and vegetable-growing: "We want to ensure that many of the beneficiaries move from dependency to self-sufficiency and towards building the selfesteem of women." 10

Fraser-Moleketi's views were shared by other leading ANC policymakers. The influential chairman of the parliamentary portfolio committee overseeing social welfare, Cas Saloojee, acknowledged the importance of a social safety net but at the same time insisted that even a "comprehensive" system of social security would limit "the social security obligation of the state ... to the poorest of the poor, the most vulnerable and the unemployed". (In fact, the state provided almost no support for the unemployed). Saloojee continued: only by reducing the expense of social grants could the state divert "funds that are currently committed to social security ... to developmental social welfare services":

We have got to acknowledge that social security cannot solve the problem of the magnitude of poverty that we face, but that such financial resources can make a significant impact on job creation and empowerment of people to become self-reliant. The old expression 'Give a man a fish, and you feed him for a day; teach him to fish, and you feed him for a lifetime', comes to mind again. ${ }^{11}$

The ANC viewed developmental efforts, including training programmes, as the priority. The real value of old-age pensions and disability

\footnotetext{
${ }^{9}$ Mail and Guardian, 9 May 1997.

${ }^{10}$ Fraser-Moleketsi, Hansard, House of Assembly, debate on the State of the Nation Address, 9 Feb 1999, col. 305; also budget vote, 19 March 1999, col.2851-5.

${ }^{11}$ Saloojee, Hansard, House of Assembly, Budget vote, 19 March 1999, col 2859-60.
} 
grants was allowed to fall, and total expenditure on social grants fell as a proportion of GDP.

President Mandela himself mentioned social grants only twice in his six State of the Nation Addresses between 1994 and 1999. In his first, in 1994, he mentioned that his government would address the backlog of applications for old-age pensions. In his last, in 1999, he said that pensions and disability grants would be raised, by a small amount—although this was not enough to raise their real value to the level when he had become president five years before. Mandela never mentioned the new Child Support Grants in his State of the Nation Addresses. By contrast, he mentioned development a total of 89 times in the six addresses. ${ }^{12}$

\section{Zola Skweyiya's Partial Reframing of Poverty (1999-2009)}

In mid-1999, following the election, the new president, Mbeki, appointed a new Minister of Social Welfare, Zola Skweyiya. Skweyiya was considerably older than his predecessor (he was born in 1942) and came from a rather different background. First, he knew from personal experience what it meant to go to bed without supper or to go to school without breakfast. ${ }^{13}$ Second, he was immersed in the African mission-educated, Christian political tradition that was liberal on many issues but paternalistically conservative on others. His schooling had concluded the elite Lovedale College - established by missionaries more than a century earlier-where he overlapped with Thabo Mbeki. He went on to the University of Fort Hare before following Mbeki into exile. Like Mbeki, Skweyiya did not return to South Africa until 1990. Whilst in exile he studied law (completing a PhD in communist East Germany) and held a series of largely diplomatic posts for the ANC as well as setting up its Legal and Constitutional Affairs Department. Both before and after 1990 he represented the ANC at the UN Commission for Human Rights. He

\footnotetext{
${ }^{12}$ Mandela, State of the Nation Addresses, 1994-1999; available on https://www.gov.za/ state-nation-address.

${ }^{13}$ Hansard, House of Assembly, Social Development budget vote, 27 March 2003.
} 
was firmly part of the ANC's "nationalist", non-Communist wing. In 1994, Mandela appointed him minister of Public Service and Administration. In 1999, his old friend Mbeki moved him to the Ministry of Social Welfare.

At the time of his appointment as minister of Social Welfare in 1999, fewer than 3 million grants were paid monthly. When he stepped down, ten years later, about 13 million grants were paid monthly-an increase of an average of 1 million grants per annum over Skweyiya's ten years as minister. Over the same period, expenditure on grant payments approximately trebled, in real terms (i.e. taking inflation into account). Whilst economic growth was strong across much of this period, expenditure also grew significantly in relation to GDP. As subsequent studies made clear, this expansion of social assistance played a major part in the slow reduction of income poverty (van der Berg et al. 2006; Leibbrandt et al. 2010).

This future expansion of social assistance was not suggested in Skweyiya's first comments after becoming minister. He initially seemed to take up where Fraser-Moleketi had left off. His Department continued to emphasise "the promotion of self-reliance to reduce dependency on ... social grants" (South Africa 1999: 6) and was renamed the Department of Social Development. It adopted a "Ten Point Plan" that listed its priorities, in apparent order of importance: the first priority was "restoring the ethics of care and human development in all welfare programmes" (which entailed "the rebuilding of families and communities"); the second was "developing and implementing an integrated poverty eradication strategy"; only third did the Plan list social security (South Africa 2000).

In early 2000, however, Skweyiya struck a different note in his first major speech as Minister of Social Welfare. Skweyiya began by quoting President Mbeki on the importance of a "humane and people-centred society". ${ }^{14} \mathrm{He}$ went on to describe some of what he had learnt over the past year whilst travelling around South Africa:

I met the grandmother in the rural village of Inanda caring for a HIVpositive daughter, the girl-child taken from school to care for her siblings,

\footnotetext{
${ }^{14}$ Hansard, House of Assembly, Welfare budget vote, 18 April 2000, col. 2661.
} 
and the single mother who cannot find a job. I saw the pain on the face of a young child who had been abused and raped in Claremont near Durban. I heard the frustration of a father with disability who wants to learn new skills in Maokeng, Kroonstad, but has nowhere to turn to. I listened to the anguish of the devastating effect of the loss of a pension or grant in poor families. ${ }^{15}$

He concluded that "much more needs to be done" to reverse the degradation and marginalisation of the poor. ${ }^{16}$ Through his "encounters" with the poor, Skweyiya learnt something that researchers subsequently confirmed: Social grants were very important in sustaining dignity (see, especially, Wright et al. 2014, 2015).

The chairman of the parliamentary portfolio committee, Saloojee, followed Skweyiya's lead, striking a more positive tone. He referred explicitly to the need to restore "the dignity of all of our people" through poverty reduction - and then emphasised repeatedly the importance of social grants to the relief of poverty. He lamented the lack of an "integrated poverty strategy" but envisaged an expansion of social assistance, especially through the Child Support Grant. "The initial strategy for targeting our country's poorest children is to be followed by broader coverage, to ultimately include all the country's poor", he said. "If these children go hungry and have parents with no visible means of support, we have failed these children by not providing them with support to ensure their protection and development". ${ }^{17}$ The government would be guided by the recommendations of a Committee of Inquiry (to be chaired by Professor Viviene Taylor) appointed to examine what might be entailed in a more comprehensive system of social security.

In comparison with the five years of the Mandela presidency, this was an extraordinary embrace of social assistance. It was dressed up in the discourse of dignity that Mandela (and his then vice-president, Mbeki) had used previously, but the discussion of social assistance gave this discourse new substance. In the late 1990s the discourse of dignity had been embedded in South Africa's new Constitution (in 1996) and in

\footnotetext{
${ }^{15}$ Ibid., col. 2663.

${ }^{16}$ Ibid., col. 2663-4.

${ }^{17}$ Ibid., col. 2673-7.
} 
subsequent constitutional jurisprudence, giving the discourse heightened prominence and legitimacy. The 1996 constitution recognised respect for a person's "inherent dignity" as one of the founding values underpinning the new constitutional order. This represented a "stark and dramatic" break with the apartheid past (as then Chief Justice Mahomed put it in 1998, quoted in Chaskalson 2000: 193). As Constitutional Court Justice O’Regan elaborated in 1995:

Respect for the dignity of all human beings is particularly important in South Africa. For apartheid was a denial of a common humanity. Black people were refused respect and dignity and thereby the dignity of all South Africans was diminished. The new Constitution rejects this past and affirms the equal worth of all South Africans. Thus recognition and protection is the touchstone of the new political order and is fundamental to the new Constitution. (quoted in Chaskalson 2010: 1381)

O'Regan wrote this in connection to capital punishment, which the Constitutional Court declared unconstitutional. Dignity was central also to judgements on issues such as corporal punishment and gay marriage. But dignity had very clear relevance also to the interpretation of social and economic rights, as Arthur Chaskalson (the then president of the Constitutional Court and later also Chief Justice) acknowledged explicitly. Section 27 of the Constitution enshrined "the right to have access to ... social security, including, if they are unable to support themselves and their dependents, appropriate social assistance"; it committed the state to taking "reasonable legislative and other measures, within its available resources, to achieve the progressive realization" of this right. As Chaskalson commented in 2000: "These rights are rooted in respect for human dignity, for how can there be dignity in a life lived without access to housing, health care, food, water or in the case of persons unable to support themselves, without appropriate assistance?" Chaskalson went on to explain that the Constitution did not "contemplate" complete equality of goods or wealth. Rather, it required the state "to show respect and concern" for those citizens whose basic needs were not being met at the same time as taking into account "the general interests of the community concerning the application of resources", through taking 
"reasonable legislative and other measures, within its available resources, to achieve the progressive realisation" of access to the goods that were minimally necessary for human dignity (Chaskalson 2000).

Skweyiya's concern for the dignity of the poor framed his positive attitude towards social grants. In 2001, he described social assistance as "the Government's primary investment in poverty alleviation" (emphasis added). He added that, whilst "the current grant amounts are not sufficient to address large-scale poverty, deprivation and inequality in South Africa", the government would "continue to increase spending on social assistance as resource constraints allow". ${ }^{18}$ His department's Annual Report for 2001 similarly identified social security as-for the first time-its primary priority, acknowledging that its developmental training programme for unemployed women had floundered (South Africa 2001: 9).

This new perspective was far from hegemonic, however, as soon became clear in the debate over the Taylor Committee's report. In its somewhat chaotic report, completed in early 2002, the Taylor Committee endorsed the hegemonic developmental approach to "social protection": public health, education and other services were necessary to enhance the capabilities of the poor. In the short term, however, the Committee recommended that the holes in the existing safety net be filled through the extension of the Child Support Grant to the age of 18 and then the introduction of a modest "basic income grant" for all adults (South Africa 2002). Skweyiya himself initially seemed favourable. But he faced strong opposition within the ANC leadership and government. The powerful government spokesman Joel Netshitenzhe reiterated the mantra that able-bodied adults should not receive "handouts" but instead should be helped to "enjoy the opportunity, the dignity and the rewards of work". The government would not support a basic income grant, he said, because it had a rather different "philosophy". ${ }^{19}$

The proposed basic income grant never attracted significant support within the ANC leadership: grants for unemployed adults were routinely

\footnotetext{
${ }^{18}$ Hansard, House of Assembly, Social Development budget vote, 3 April 2001, col 1956-7.

${ }^{19}$ Sunday Times, 28 July 2002. See also Matisonn and Seekings (2003); Meth (2004); Barchiesi (2007).
} 
denounced as "handouts". Pensions for the elderly were never really questioned (although the government did resist lowering the age at which men became eligible for old-age pensions). The disability grant became more controversial over time, with ANC MPs voicing concerns that ablebodied people were receiving grants or, even, that they were contracting HIV in order to access grants (Kelly 2013). The most controversial issue, however, was the Child Support Grant, paid mostly to poor mothers. Opponents argued either that it was not affordable or that it encouraged undesirable behaviour. The question of affordability brought Skweyiya into conflict with, especially, the powerful Minister of Finance, Trevor Manuel. By challenging the supposed unaffordability of expanded grants, rather than contesting the philosophy, Skweyiya put Manuel on the defensive:

The ANC will not be bamboozled into doing things that it knows are not possible. We would like to give each and everybody that basic income grant. We would like to ensure that each and every family eats every night. The basic question is, how do we do that? We have a problem here. We introduced the child support grant to be given to each and every child under the age of seven ... Up to the present moment half a million children are still not getting that. The money is there, but the question is how to bring it to the people. ${ }^{20}$

Under pressure, the government did announce that the age limit for Child Support Grants would be raised (in phases, between 2003 and 2005) from a child's 7 th birthday to the child's 14 th birthday. ${ }^{21}$ Although President Mbeki himself made this announcement in 2003, he subsequently seemed less than enthusiastic. One year later, in his 2004 State of the Nation Address, he pointedly did not include social grants in his list of the ANC government's achievements since 1994. Instead, he referred to the need to "create the conditions ... to reduce the numbers of our people dependent on social grants". ${ }^{22}$ The ANC did decide, however, to emphasise strongly the rising number of social grants in its campaign for

\footnotetext{
${ }^{20}$ Hansard, House of Assembly, Social Development budget vote, 27 March 2003.

${ }^{21}$ Mbeki, State of the Nation Address, 14 Feb 2003.

${ }^{22}$ Mbeki, State of the Nation Address, 6 Feb 2004.
} 
the country's third democratic general election in April 2004-although it did not promise any significant expansion of social grants, emphasising instead the prospect of one million new "job opportunities" through the workfare programme (ANC 2004). Following the elections, Mbeki delivered a second State of the Nation Address. Now he did refer to the consolidation of a "social security net". But he also reiterated the imperative of reducing dependency on social grants, declaring that "a society in which large sections depend on social welfare cannot sustain its development". ${ }^{23}$ That same year the government launched its new, "Expanded" Public Works Programme, to provide a small proportion of unemployed people with some of the "dignity of work" - a concept with deep roots in the ANC and South Africa (Barchiesi 2011; Ferguson 2015)_and, through enhancing skills and the experience of work, "reduce, over time, the proportion of our people who subsist solely on social grants". 24

Over the following years, Skweyiya balanced the defence of selective social assistance - for deserving categories of poor people - with the kind of developmental rhetoric that had prevailed prior to 2000. In a 2005 debate, he emphasised that his department had "sought to ensure the provision of comprehensive social protections services against vulnerability and poverty to as many deserving people as possible", including through expanded social assistance programmes. At the same time, he trotted out an old denunciation of fraud. His department had offered indemnity to anyone who came forward and admitted to receiving a grant illegally. A total of 30,000 people had done so, resulting in considerable savings. But "we are not satisfied with the result of the campaign" because "more people should have come forward". Now, the law would be enforced, beginning with public servants and the syndicates behind fraud. Also, he suggested, the sustainability of the social protection system depended on poor people taking advantage of improved economic opportunities so as to become less dependent on the state. ${ }^{25}$

\footnotetext{
${ }^{23}$ Mbeki, State of the Nation Address, 21 May 2004.

${ }^{24}$ Skweyiya, 2004 budget vote, Hansard, 3 June 2004, col. 594.

${ }^{25}$ Skweyiya, 2005 budget vote, Hansard, 5 April 2005, col. 1333-1400
} 
Skweyiya's message may have been mixed but was far more positive about social grants than many of his colleagues in the ANC. One ANC MP invoked the need for "moral regeneration" whilst declaring that modest grants would merely create dependency. "The ANC does not believe that it was supposed to create a South Africa where people would depend on the state for food, without opportunities for development", he proclaimed, speaking in Zulu; "it is not part of the African culture to wait to be fed instead of doing things on your own". ${ }^{26}$ Another ANC MP, reinforced this point:

Our people are not waiting for handouts. The budget is such that people can provide for themselves. People have heeded the call: 'Wake up and do it yourself". In this budget we are trying to support them in their efforts to become independent. ... In the rural areas people plough and do different kinds of job to sustain a living.

In response to opposition parties' rhetorical support for the expansion of social assistance through some kind of basic income grant, this ANC MP declared that "the basic income grant that [an opposition MP] is referring to is not the solution for the needs of the people. People have their own way of living, not by getting handouts". ${ }^{27}$ Skweyiya felt the need to rebut his own colleague, noting that "it had been proved beyond any reasonable doubt" that grants did not create a culture of dependency (see also Surrender et al. 2010; Ferguson 2015). He also took care to point out that the government's caution was not because ANC leaders were "scrooges", but rather because of resource constraints. ${ }^{28}$

Skweyiya successfully legitimated social grants for selected categories of deserving poor, not for the unemployed (the dreaded "handouts"). He did not do away entirely with the earlier developmentalist doctrine. His Department for Social Development initiated a new developmental programme (Gwebindlala) to "provide income support while simultaneously

\footnotetext{
${ }^{26}$ Hansard, House of Assembly, Social Development budget vote, 5 April 2005, col. 1350-7 (Lewis Nzimande).

${ }^{27}$ Hansard, House of Assembly, Social Development budget vote, 5 April 2005, col. 1389 (B. Solo).

${ }^{28}$ Hansard, House of Assembly, Social Development budget vote, 5 April 2005, col. 1398-1400 (Skweyiya).
} 
developing the human capital of beneficiaries through skills development and job-placement services". ${ }^{29}$ This rhetoric was not unlike the rhetoric associated with the welfare state in Europe and elsewhere, except that in the South African context programmes like this provided support and services for very few people, whilst a very large number of people received no income support at all and many others received very modest income support. The developmentalist discourse appealed to the ANC's more conservative MPs, one of whom commented that "maintaining our lives through charity is not black people's way of living ... Whenever we found ourselves in situations beyond our control, we would be given a cow. Although one would not get ownership of the cow, one would be able to get milk and plough the fields" ${ }^{30}$

The distinction between those poor who deserved grants (i.e. the elderly, disabled, children and caregivers) and those who needed to be put to work meant that government documents both celebrated and criticised grants. A discussion document released in early 2007 emphasised the "dignity of work". It criticised social grants that lacked any mechanism for helping beneficiaries to find work and explicitly advocated more efforts to promote the kinds of employment appropriate for people with minor disabilities (and currently receiving disability grants). The document advocated "active labour market measures, skills development programmes, special employment and labour-intensive development programmes and labour-intensive government services", as well as further "consideration" of an "aggressive expansion" of public works programmes: "the drive to get all South Africans working when they are able to do so must become a central preoccupation" (South Africa 2006a). ${ }^{31}$ Similarly, the Department of Social Development's “Strategic Plan” for 2006-2010 referred to its continuing commitment to a "paradigm shift" from a welfarist approach to "developmental welfare" (South Africa 2006b). The ANC's 2007 policy discussion document on "social transformation" also emphasised the "dignity of work" and the importance of public works

\footnotetext{
${ }^{29}$ Hansard, House of Assembly, Social Development budget vote, 28 March 2006, col. 986 (Dr Jean Benjamin (Deputy-Minister).

${ }^{30}$ Hansard, House of Assembly, Social Development budget vote, 28 March 2006, col. 1000 (B. Solo).

${ }^{31}$ Later, in the early 2010s, the term "activation" entered the policy discourse in South Africa.
} 
programmes as an alternative to social assistance. Arguing (rather unclearly) against a basic income grant, the ANC suggests that discussion should take place "in the context of our challenges as a developmental state rather than against the ideological backdrop of a welfare state" (ANC 2007: 3, emphasis added). The primary emphasis of the "attack on poverty" should entail empowering people "to take themselves out of poverty". The social safety net should be limited to the protection of "the most vulnerable in our society" (ibid: 2), implying specific groups of deserving poor rather than the poor in general.

The government's overall approach thus remained resolutely developmental: poverty reduction required simply that the benefits of economic growth be "shared". In early 2006, the government launched its Accelerated and Shared Growth Initiative for South Africa (AsgiSA). This envisaged that poverty and unemployment rates would be reduced by one half through increasing the economic growth rate (to 6 per cent p.a.) and sharing growth, primarily through absorbing more labour into the "mainstream economy". Key elements of the plan included increased public investment in infrastructure, accelerated skill development and reducing the regulatory burden on small- and medium-sized businesses (South Africa 2005). Whilst economic growth rates remained strong up to the global economic crisis of 2008-2009, the benefits were not shared widely: wages rose but employment in the formal economy remained stagnant.

Skweyiya recognised that he needed to rebut the lingering distaste for social grants among many of his ANC colleagues, which they often dressed up in their commitment to developmentalism. Skweyiya's solution was to commission research that would provide the data to undermine his colleagues' objections. The first of the ensuing reports, completed in late 2006 and presented to Cabinet, dispelled "assertions that our social assistance programme encourages teenage pregnancies, that children are fostered for the purpose of accessing grants, and that people with disability will harm themselves in order to continue accessing social grants" (as Skweyiya reported to Parliament in 2007). ${ }^{32}$ Further reports

${ }^{32}$ Hansard, House of Assembly, Social Development budget vote, 28 March 2007, col.2393 (Skweyiya). 
examined the effects of grants on poverty alleviation and development, the benefits of raising the age limit on the Child Grant, the means-test and conditions on grants.

These reports did not persuade all ANC leaders that social grants should be expanded further. At a national conference in December 2007, the ANC resolved that the Child Grant age limit be "gradually extended to eighteen years" and the age threshold for men to receive the old-age pension be reduced to sixty years. But the ANC resolved also that "grants must not create dependency and thus must be linked to economic activity" (ANC 2007). In his State of the Nation Address at the beginning of 2008, President Mbeki-who had been defeated by his rival Jacob Zuma in the contest for the presidency of the party at the December conference-referred to the age threshold for pensions but pointedly did not mention the Child Grant. When, a few days later, Skweyiya told the Parliamentary Portfolio Committee and then announced in a press briefing that the age limit for the Child Grant would be increased to 18 years, this was almost immediately contradicted by the minister of Finance.

Less than a year later, however, the government confirmed that the age limit would be raised. ANC leaders (including the Minister of Finance, Trevor Manuel) attributed the government's shift to the "compelling evidence" in "recent research" that the Child Grant had reduced child poverty. He (and interim President Motlanthe in his 2009 "State of the Nation Address") seems to have been referring not to the research commissioned by Skweyiya but to research commissioned by the Treasury that attributed the decline in income poverty (and child hunger) in the early 2000s to the Child Grant.

Unsurprisingly, ANC leaders did not draw attention to two other factors: factional politics within the ANC combined with the imminence of the 2009 elections. In late 2007, an eclectic coalition supported Jacob Zuma and ousted Mbeki as party leader; one year later the coalition ousted Mbeki as president of the country. At the time this was widely interpreted as a "shift to the left" within the ANC (e.g. Proudlock 2011: 154; and generally Booysen 2011). The new leadership proved to be more opportunistic than left wing. The decision to raise the Child Grant age limit — which was not made until almost one year after the pro-Zuma coalition secured control over the ANC_-seems to have been due more 
to the sidelining of Mbeki personally and electoral opportunism. The ANC in 2009 faced a resurgent parliamentary opposition (comprising both the Democratic Alliance, supported largely by racial minorities, and the new Congress of the People led by Mbeki supporters who defected from the ANC) and widespread extra-parliamentary protests (the socalled "rebellion of the poor"-Alexander 2010). Under Zuma, the ANC sought to project itself as a party that had both achieved much hitherto and was now regenerated under new leadership (Beresford 2015; Booysen 2011). Crucially, the "new" ANC needed to demonstrate that the government was doing something new and positive to reduce poverty. Given that most of the other political parties were calling for the Child Grant age limit to be raised, the ANC chose to emphasise in its election manifesto that its expansion of social grants had "pushed back the frontiers of poverty" (ANC 2009).

More generally, the courts and civil society activists had transformed the normative and discursive context. Activists and the courts rarely agreed on precisely how social and economic rights should be operationalised, but they concurred, for the most part, on the underlying understanding of "dignity" and community, rooted in a Kantian moral philosophy. They thus continued to strengthen and legitimate the alternative discourse around social grants adopted (at least sometimes) by Skweyiya. The strongest judicial statement of this was in two cases in which the Constitutional Court ordered the government to pay pensions and grants to legally resident non-citizens on the same basis as citizens. In one of these judgements, Justice Mokgoro emphasised the constitutional commitment to building a "caring society". Permanently resident noncitizens should not be abandoned "to destitution if they fall upon hard times"; the state should not force them into "relationships of dependency upon families, friends and the community in which they live" (Mokgoro 2004). The government resisted legal efforts to expand social assistance programmes. Officials in Skweyiya's own department filed affidavits opposing cases brought by civil society activists to expand social grants. Moreover, the courts themselves were generally reluctant to push the executive too far or too fast, especially when policy shifts had major financial implications. In a series of major cases, the courts decided that the government was not obliged to provide very expensive healthcare or 
housing for all, nor to extend old age pensions or child grants. In a case that provoked the ire of civil society activists, the Constitutional Court decided unanimously against determining any "minimum core" of public services that citizens could claim under the constitution (see, e.g. Langford et al. 2013). But the courts ensured that the experience of poverty continued to be viewed as an indignity that society had to address. As one legal scholar put it, drawing on the work of American philosopher Martha Nussbaum, "conditions of poverty are not a reflection of the moral blameworthiness of groups experiencing poverty rather they reflect how we as a society have failed to value human dignity". Respect for human dignity requires "redressing the social and economic conditions of those whose capacity for development and agency is stunted by poverty" - and accepting shared responsibility to enable the poor to live as equal members of society (Liebenberg 2005: 12-14).

Skweyiya's complex defence of social grants for deserving categories of poor people but preference for job creation for able-bodied adults entailed an understanding of "social citizenship" and solidarity that accorded with popular opinion and norms. Quantitative and qualitative evidence suggested that most South Africans shared a strong sense that a large number of people were deserving of the support of society as a whole. Almost all South Africans concurred that differences in income (as well as differences in wages among working people specifically) were too large, and that the government should redistribute from rich to poor (Roberts 2014). Most South Africans, without regard to race or class, not only supported the principle of tax-financed pensions for the elderly but believed that the value of the pension should be increased (even if it meant that they themselves paid higher taxes). Most South Africans also included in the "deserving poor" people who were unable to work because they were disabled or sick, or who were caring for children or the elderly (Seekings 2007, 2010). There was even some evidence that people believed that the unemployed had some "right" to some kind of support (e.g. CASE 2005; Roberts 2014). At the same time, there was widespread scepticism about social grants for unemployed adults and outright condemnation of grant recipients who "misspent" their grants (e.g. on alcohol) (Seekings 2007; Dawson and Fouksman 2020). 


\section{The Conservative Backlash: The Social Question After Skweyiya (from 2009)}

Skweyiya did not stand for re-election to parliament in 2009. His immediate successor, Edna Molewa, was Minister of Social Development for a little more than one year before she was in turn replaced (in November 2010) by Bathabile Dlamini. Dlamini, who was a loyal member of the faction around Zuma, remained minister until Cyril Ramaphosa ousted Zuma as president in February 2018. Dlamini's term as minister-lasting more than seven years-is remembered primarily for the controversy surrounding the award of the national contract to pay social grants to the multinational company Cash Paymaster Services and her ensuing incompetence and dishonesty in solving the crisis (Gronbach 2017). But it was also a period of conservative reaction against the expansion of the social assistance system under Skweyiya, albeit a reaction that did not lead to any clear retrenchment of social grant programmes. Under Dlamini, the Department of Social Development began to emphasise more strongly the need to strengthen the family so that the family could take over from the state much of the responsibility for care. A 2012 White Paper emphasised "self-reliance", that is, the converse of dependency (South Africa 2012a).

President Zuma himself provided a clear line to his ministers. In 2011, he reportedly told businessmen that "we cannot be a welfare state"; taxpayers should develop the country "rather than feed the poor". ${ }^{33}$ This might sound like an argument against further expansion, but Zuma later made clear his own patriarchal criticism of paying grants to young women. In a 2015 speech to traditional leaders, Zuma branded teenage mothers as irresponsible bad mothers, claimed that they were not using the child support grant for their children and suggested that they were cheating the system. Instead of being allowed to drop out of school, Zuma suggested they should be sent to somewhere like Robben Islandthe apartheid-era prison for political prisoners - where they could complete their schooling, thus empowering them to work and support their

\footnotetext{
33 “Zuma says S. Africa can't be welfare state: SAPA”, 24 November 2011; https://af.reuters.com/ article/topNews/idAFJOE7AN04C20111124.
} 
children themselves. If they were to be given grants, then the grants should not be paid in cash, which recipients could spend as they like, but rather in vouchers that could only be used to buy designated items. Zuma, together with many other conservatives, saw the "problem" in terms of the supposed immorality of young women, not the economic and other structural factors that encouraged teenagers to become mothers. ${ }^{34}$ Other ministers worried about "dependency" with regard to other areas of public policy. Announcing a new model for funding public housing, Minister Lindiwe Sisulu, for example, stated that "giving free houses creates a dependency syndrome". The government "cannot continue giving out free houses anymore", but instead would "give people subsidies so that they can build houses themselves". ${ }^{35}$ The ANC adopted a very ambivalent stance towards social protection in its election manifestos (ANC 2014).

Under Zuma, the government and ANC emphasised poverty as much as previous governments in their plans and resolutions. Inequality was emphasised even more strongly than hitherto. But the plans emphasised the developmental state not the welfare state. The most prominent plan completed during this period-the 2012 National Development Plan (South Africa 2012b) — focused on the reduction of poverty and inequality. As the Plan made clear in its chapter on social protection: "These goals can be achieved by building capabilities that enable individuals to take part in the formal economy and in other parts of society" — reversing the effects of apartheid. "If apartheid destroyed opportunities for the majority of the population and trapped them in poverty, the challenge for the next 20 years is to rebuild the opportunity structures and help individuals develop the capabilities to live the life they wish to lead". Whilst "employment is the best form of social protection", the state should continue to provide for those who cannot provide for themselves-in "labour market and employment friendly" ways. A "balance" should be struck between the provision of a safety net and "incentivizing and supporting

\footnotetext{
${ }^{34} \mathrm{http}: / / \mathrm{mg}$. co.za/article/2015-03-11-zuma-send-teenage-mums-to-robben-island.

${ }^{35}$ Xaba, V. 2016. No more free RDP houses to curb dependency. The Sowetan http://www.sowetanlive.co.za/news/2016/04/10/no-more-free-rdp-houses-to-curb-dependency.
} 
individuals to develop their own ability to respond to shocks and save for rainy days". The Plan envisaged replacing the existing, and admittedly patchy, safety net with a comprehensive "social floor"-borrowing the concept promoted by the ILO, culminating in the ILO's 2012 Recommendation 202 on Social Protection Floors-but the Plan proposed no new programmes that might actually achieve the ambition. Social assistance would be expanded only insofar as more efforts would be made to ensure that eligible individuals applied for and received existing grants. The "social floor" for the unemployed working-age population would entail not social grants but rather "various active labour market initiatives such as public works programmes, training and skills development, and other labour market related incentives". The Plan seemed to envisage vaguely a massive expansion of these initiatives, but there were few specific proposals. The Plan also worried about the continued affordability of existing programmes.

Zuma's State of the Nation Addresses indicate his disinterest in social grants. In 2009 he told Parliament that "We are mindful of the need to link the social grants to jobs or economic activity in order to encourage self-reliance amongst the able-bodied". In 2011 he repeated this point: "Since we are building a developmental and not a welfare state, the social grants will be linked to economic activity and community development, to enable short-term beneficiaries to become self-supporting in the long run." He regularly reported on action to prevent fraudulent grant payments. From 2012 he reported the rising number of beneficiaries-due to decisions taken before he took office, combined with population growth-but otherwise barely mentioned grants at all. ${ }^{36}$

The ideological shift within the ANC may have corresponded with deepening ambivalence among the public (although it is unclear whether elite discourse led public opinion or vice versa). Both quantitative and qualitative research suggests that support for social grants in South Africa is conditional on the behaviour of the recipients. More than 50 per cent of respondents in a representative countrywide survey in 2015 agreed that young women spent too much of their grants on alcohol. One half of the sample also agreed that young women have children so that they can access a child grant. When the same questions were asked in a 2018

\footnotetext{
${ }^{36}$ https://www.gov.za/state-nation-address\#2009.
} 
survey, public opinion seems to have become more critical. As many as 60 per cent of respondents agreed that young women spent too much of their grants on alcohol. In both 2015 and 2018, more than half of the respondents agreed that adults who were physically able to work should be required to do so in return for any money received from the government. In 2018, the same proportion agreed that citizens become lazy when they rely on government grants or pensions. ${ }^{37}$ Roberts (2014) reports that support for the redistribution of income by the government seems to have declined modestly (by some but not all measures) between the mid-2000s and the early 2010s. If so, this may be driven by declining concern with inequality and support for government action among the growing African middle classes (Seekings 2017b). More and more qualitative researchers find evidence that at least some poor people are quite critical of the payment of social grants, especially to young women (e.g. Mosoetsa 2011; Blake 2018).

In practice, the Zuma governments of 2009-2018 presided over a marked lack of development and job creation. As became clear later, large parts of the state were "captured" by private interests, who used the state for personal enrichment rather than national economic development or poverty reduction. The government's corrupt allocation of the national contract to pay social grants and its inability to address the subsequent abuse of grant payments were indicative of the broader malaise.

Skweyiya - like Mandela—was, for the most part, conservative. But his conservatism was paternalistic, unlike the more reactionary patriarchal conservatism articulated by Zuma. Skweyiya was surely horrified by "state capture" and the crisis of grant payments under Zuma. Skweyiya believed that all people, however poor, were members of the broader community and had some claim to collective resources, alongside a general responsibility to strive for self-reliance. Whilst he was minister, childcare grants were rolled out for an additional ten million children, at a cost of more than 1 per cent of GDP. This was, to his mind, the right thing to do. The social question, for Skweyiya, meant assisting poor people who were unable to satisfy their own minimum needs through their own

\footnotetext{
${ }^{37}$ Data from 2015 Comparative National Election Study and 2018 Afrobarometer survey, my analysis.
} 
efforts. For Zuma, in contrast, the social question appears to be a cultural or moral one: decadent urban and/or Western morality needs to be rolled back, and a disciplined and patriarchal African social order re-established.

Skweyiya would have been unlikely to preside over the expansion of the welfare state had he not taken over what was already a welfare state, notwithstanding the hostility or ambivalence towards it both within the National Party (under apartheid) and the ANC (in the period 1994-1999). The reframing of the "social question" in South Africa in the early 2000s was, in important respects, path dependent: existing, apartheid-era social assistance programmes had helped to cement an understanding within the general population of who is deserving and who is not. This permeated into elite thinking in the late 1990s sufficiently to deter major programmatic retrenchment and in the 2000s to facilitate programmatic expansion. Skweyiya himself was party to a long tradition of paternalist conservatism within South Africa's African elite. Nonetheless, there was nothing inevitable about the expansion of social assistance under Skweyiya. The ANC might have chosen other programmes to shore up its electoral support among the poor. It might have adopted a more patriarchal line long before Zuma became president.

The first two phases in the post-apartheid reframing of the social question involved some influence of ideas from abroad. The developmental turn from "welfare" to "social development" was influenced by the ideas articulated by Midgley. It may also have been influenced by the large number of Nordic, other European and Australian policy consultants who flooded into South Africa in the 1990s, most of whom fuelled a vision of skill-intensive, high-wage job creation, with unemployment being tackled through active labour market policies. Skweyiya's advocacy of expanded social assistance coincided with the global embrace of social assistance by international organisations (von Gliszczynski and Leisering 2016). Under Skweyiya, the Department of Social Development commissioned research from a series of foreign researchers to support his argument for expansion. In both phases, however, reframing was rooted firmly in the convictions of South African policymakers. Whilst many of the individual technocrats held more progressive views, the dominant approaches within the ANC leadership were all conservative, whether 


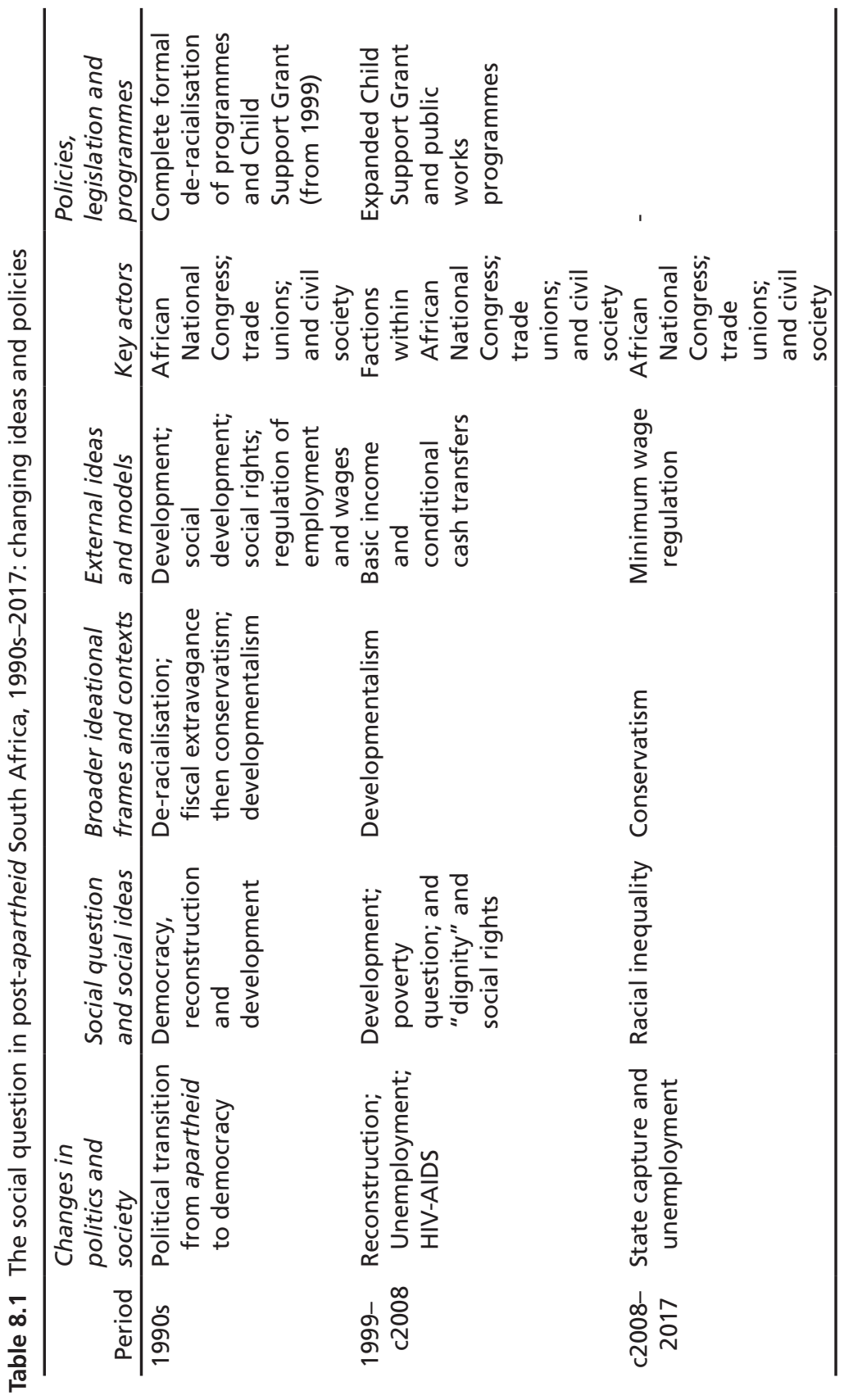


developmental (in the late 1990s), paternalistic (Skweyiya) or patriarchal (under Zuma). The result was that a social (protection) floor or comprehensive safety net remained an ambition rather than a reality. Table 8.1 summarises the analysis.

\section{References}

Alexander, Peter (2010) Rebellion of the poor: South Africa's service delivery protests-a preliminary analysis. Review of African Political Economy 37,123: 25-40.

ANC (1994) The reconstruction and development programme. Johannesburg: African National Congress.

ANC (2004) A people's contract to create work and fight poverty. 2004 Election Manifesto. .Johannesburg: African National Congress.

ANC (2007) Social Transformation. African National Congress Policy Discussion Document. Johannesburg: African National Congress.

ANC (2009) Working together we can do more. 2009 election manifesto. Johannesburg: African National Congress.

ANC (2014) Together we move South Africa forward. 2014 Election Manifesto. Johannesburg: African National Congress.

Barchiesi, Franco (2007) South African debates on the basic income grant: Wage labour and the post-Apartheid social policy. Journal of Southern African Studies 33,3: 561-75.

Barchiesi, Franco (2011), Precarious Liberation: Workers, the state, and contested social citizenship in postapartheid South Africa (Albany: State University of New York Press).

Beresford, Alexander (2015) South Africa's political crisis: Unfinished liberation and fractured class struggles. London: Palgrave Macmillan.

Blake, Rosemary (2018) The price of the grant: The social cost of child support grants for female caregivers and their extended networks. CSSR Working Paper 412 (Cape Town: Centre for Social Science Research, University of Cape Town).

Booysen, Susan (2011) The African National Congress and the regeneration of political power. Johannesburg: Witwatersrand University Press.

Bramble, Tom, and Franco Barchiesi (eds.) (2003) Rethinking the Labour Movement in the new South Africa. Aldershot: Ashgate. 
Buhlungu, Sakhela (2010) A paradox of victory: COSATU and the democratic transformation in South Africa. Pietermaritzburg: UKZN Press.

CASE (2005) Investigation into the increase in uptake of disability and care dependency grants since December 2001. Johannesburg: Community Agency for Social Enquiry.

Chaskalson, Arthur (2000) The third Bram Fischer lecture - Human dignity as a foundational value of our constitutional order. South African Journal on Human Rights 16,2: 193-205.

Chaskalson, Arthur (2010) Dignity as a constitutional value: A South African perspective. American University International Law Review 26, 5: 1377-1408.

Davie, Grace (2015) Poverty knowledge in South Africa: A social history of human science, 1855-2005. Cambridge: Cambridge University Press.

Dawson, Hannah, and Elizaveta Fouksman (2020) Labour, laziness and distribution: Work imaginaries among the South African unemployed', Africa 90, 2: 229-51.

Ferguson, James (2015) Give a man a fish: Reflections on the new politics of distribution. Durham, NC: Duke University Press.

Gray, Mel (2006) The progress of social development in South Africa. International Journal of Social Welfare 15 (supplement): S53-64.

Gronbach, Lena (2017) Outsourcing the disbursement of social grants and banking the unbanked: The case of Net1 UEPS Technologies, Ltd in South Africa. M.A dissertation, University of Pretoria.

Kelly, Gabrielle (2013) Regulating access to the disability grant in South Africa, 1990-2013. CSSR Working Paper 330. Cape Town: Centre for Social Science Research, University of Cape Town.

Langford, Malcolm, Ben Cousins, Jackie Dugard and Tshepo Madlingozi (eds.) (2013) Socio-economic rights in South Africa: Symbols or substance? Cambridge: Cambridge University Press.

Leibbrandt, Murray, Ingrid Woolard, Arden Finn, and Jonathan Argent (2010) Trends in South African income distribution and poverty since the fall of Apartheid. OECD Social, Employment and Migration Working Papers no.101. Paris: Organisation for Economic Co-ooperation and Development.

Liebenberg, Sandra (2005) The value of human dignity in interpreting socioeconomic rights. South African Journal on Human Rights 21, 1: 1-31.

Lund, Francis (2008) Changing social policy: The child support grant in South Africa. Cape Town: Human Science Research Council Press.

Matisonn, Heidi, and Jeremy Seekings (2003) Welfare in wonderland? The politics of the basic income grant in South Africa, 1996-2002. In The basic 
income grant in South Africa, eds. Guy Standing and Michael Samson, Cape Town: University of Cape Town Press, 56-76.

Meth, Charles (2004) Ideology and social policy: "Handouts" and the spectre of "dependency". Transformation 56: 1-30.

Midgley, James (1995) Social development: The developmental perspective in social welfare. London: Sage.

Mkandawire, Thandika (1999) Shifting commitments and national cohesion in African countries. In Common security and civil society in Africa, eds. Lennart Wohlegemuth, Samantha Gibson, Stephen Klasen, and Emma Rothschild, Uppsala: Nordic Africa Institute, 14-41.

Mokgoro, Yvonne (2004) Judgement. in Louis Khosa and others versus Minister of Social Development and others (CCT 12/03), and Saleta Mablaule and Altinah Hlungwana versus Minister of Social Development and others (CCT 13/03), Constitutional Court of South Africa.

Mosoetsa, Sarah (2011) Eating from one pot: The dynamics of survival in poor South African households. Johannesburg: Witwatersrand University Press.

Nattrass, Nicoli, and Jeremy Seekings (2000) "Two nations": Race and economic inequality in South Africa today. Daedalus (Spring): 45-70.

Nattrass, Nicoli, and Jeremy Seekings (2019) Inclusive dualism: Labour-intensive development, decent work and surplus labour in Southern Africa. Oxford: Oxford University Press.

Patel, Leila (2005) Social welfare and social development in South Africa. Cape Town: Oxford University Press.

Patel, Leila (2014) Social workers shaping welfare policy in South Africa: The white paper for social welfare and lessons for policy practice. Centre for Social Development Perspective 14-23. St Louis: Centre for Social Development, George Warren Brown School of Social Work, Washington University).

Patel, Leila (2015) Social welfare and social development in South Africa, 2nd edition. Cape Town: Oxford University Press.

Posel, Deborah (2000) A mania for measurement: statistics and statecraft in the transition to apartheid. In Science and Society in Southern Africa, ed. Saul Dubow, Manchester: Manchester University Press, 116-142.

Proudlock, Paula (2011) Lessons learned from the campaigns to expand the Child Support Grant in South Africa. In Social protection for Africa's children, eds. Sudhanshu Handa, Stephen Devereux, and Douglas Webb, London: Routledge, 149-175.

Roberts, Ben (2014) Your place or mine? Beliefs about inequality and redress preferences in South Africa. Social Indicators Research 118,3: 1167-90. 
Seekings, Jeremy (2007) The mutability of distributive justice beliefs in South Africa. South African Journal of Sociology 38,1: 20-44.

Seekings, Jeremy (2010) Racial and class discrimination in assessments of "Just Desert" in Post-Apartheid Cape Town. In Discrimination in an unequal world, eds. Miguel Centano and Katherine Newman, New York: Oxford University Press, 63-87.

Seekings, Jeremy (2017a) The discourse of dependency and the agrarian roots of welfare doctrines in Africa: The case of Botswana. Sozialpolitik.ch 2.

Seekings, Jeremy (2017b) The social consequences of class formation among Black South Africans in the 2000s: Evidence from the South African reconciliation barometer. In Rethinking reconciliation: Evidence from South Africa, eds. Kate Lefko-Everett, Rajen Govender and Don Foster, Cape Town: HSRC Press, 111-37.

Seekings, Jeremy (2020) The National Party and the ideology of welfare in South Africa under apartheid. Journal of Southern African Studies 46,6.

Seekings, Jeremy and Nicoli Nattrass (2005) Class, race and inequality in South Africa.New Haven: Yale University Press.

Seekings, Jeremy and Nicoli Nattrass (2015) Policy, politics and poverty in South Africa. London: Palgrave.

South Africa (1995) Annual report of the Department of Welfare 1995. Pretoria: Department of Welfare.

South Africa (1996) Annual Report of the Department of Welfare 1996. Pretoria: Department of Welfare.

South Africa (1997) White Paper on Social Development. Pretoria: Department of Welfare.

South Africa (1999) Annual Report of the Department of Welfare 1998/99. Pretoria: Department of Welfare.

South Africa (2000) Ten-point Plan. Pretoria: Department of Social Development. South Africa (2001) Annual Report of the Department of Social Development 2000/01. Pretoria: Department of Social Development.

South Africa (2002) Report of the Committee of Inquiry into a Comprehensive System of Social Security for South Africa. Pretoria: Department of Social Development.

South Africa (2005) Accelerated and shared growth initiative-South Africa: A summary. Pretoria: The Presidency.

South Africa (2006a) Linking social grants beneficiaries to poverty alleviation and economic activity. Discussion document. Pretoria: Department of Social Development. 
South Africa (2006b) Strategic Plan 2006/7-2009/10, RP 22/2006. Pretoria: Department of Social Development.

South Africa (2012a) White Paper on Families in South Africa. Pretoria: Department of Social Development.

South Africa (2012b) National Development Plan 2030: Our future, make it work. Pretoria: National Planning Commission.

Surrender, Rebecca, Michael Noble, Gemma Wright, and Phakama Nshongwana (2010) Social assistance and dependency in South Africa: An analysis of attitudes to paid work and social grants. Journal of Social Policy 39, 2: 203-21.

Van der Berg, Servaas, Ronelle Burger, Rulof Burger, Megan Louw, and Derek $\mathrm{Yu}$ (2006) Trends in poverty and inequality since the political transition. DPRU Working Paper no.06/104. Cape Town: Development Policy Research Unit, University of Cape Town.

Von Gliszczynski, Moritz, and Lutz Leisering (2016) Constructing new global models of social security. How international organizations defined the field of social cash transfers in the 2000s. Journal of Social Policy 45: 325-43.

Whiteford, Andrew, Dori Posel, and Teresa Kelatwang (1995) A profile of poverty, inequality and human development. Pretoria: HSRC.

Wilson, Francis (1996) South Africa: Poverty under Duress. In Poverty: A global review, eds. Else Øyen, Seymour Michael Miller and Syed Abdus Samad, Oslo: Scandinavia University Press, 227-47.

Wilson, Francis and Mamphela Ramphele (1989), Uprooting poverty: The South African challenge. Cape Town: David Philip.

Wright, Gemma, Michael Noble, Phakama Ntshongwana, David Neves, and Helen Barnes (2014) The role of social security in respecting and protecting the dignity of lone mothers in South Africa. Oxford: Centre for the Analysis of South African Social Policy, University of Oxford.

Wright, Gemma, David Neves, Phakama Ntshongwana, and Michael Noble (2015) Social assistance and dignity: South African women's experiences of the child support grant. Development Southern Africa 32, 4: 443-57. 
Open Access This chapter is licensed under the terms of the Creative Commons Attribution 4.0 International License (http://creativecommons.org/licenses/ by/4.0/), which permits use, sharing, adaptation, distribution and reproduction in any medium or format, as long as you give appropriate credit to the original author(s) and the source, provide a link to the Creative Commons licence and indicate if changes were made.

The images or other third party material in this chapter are included in the chapter's Creative Commons licence, unless indicated otherwise in a credit line to the material. If material is not included in the chapter's Creative Commons licence and your intended use is not permitted by statutory regulation or exceeds the permitted use, you will need to obtain permission directly from the copyright holder.

(c) 